УДК 349.3:364.35]:351.72(100)

https://doi.org/10.52058/2708-7530-2022-1(19)-135-147

Король Тетяна Іллівна аспірантка кафедри публічної політики, Навчально-науковий інститут публічного управління та державної служби Київського національного університету імені Тараса Шевченка, вул. А. Цедіка, 20, м. Київ, 02000, тел.: (044) 284-69-50, https://orcid.org/0000-0001-5161-8503

\title{
ЗАРУБІЖНИЙ ДОСВІД ПУБЛІЧНОГО УПРАВЛІННЯ ФІНАНСАМИ У СФЕРІ ЗАГАЛЬНООБОВ'ЯЗКОВОГО ДЕРЖАВНОГО ПЕНСІЙНОГО СТРАХУВАННЯ
}

Анотація. У статті висвітлено здійснений автором аналіз зарубіжного досвіду публічного управління фінансами у сфері загальнообов'язкового державного пенсійного страхування та сформульовані на цій основі узагальнюючи висновки для України.

Автор зауважує, що сьогодні у світі існують різноманітні моделі побудови пенсійних систем, які відрізняються зокрема такими ознаками: масштабами участі держави у розробленні та реалізації пенсійних програм, джерелами фінансування та структурою пенсійних витрат; структурою категорій населення, які підпадають під дію певної пенсійної програми; видами пенсійних виплат; характером управління пенсійним фондом тощо. Проте традиційно виокремлюють кілька моделей пенсійних систем, що розглядаються як усталені.

Зроблено висновки щодо публічного управління фінансами у сфері загальнообов'язкового державного пенсійного страхування країн Латинської Америки та країн Європейського Союзу. Зокрема, виявлено, що для країн $Є С$ в останні роки $є$ характерним припинення активного та зростаючого соціального реформізму, стабілізація рівня соціальних витрат держави відносно до ВВП, зниження державного впливу та зміна методів і засобів соціального регулювання.

Установлено, що у більшості країн 3 ринковою економікою поряд 3 обов'язковим соціальним страхуванням отримали розвиток інші додаткові (обов'язкові та добровільні) програми соціального страхування, які охоплюють пенсії за віком, допомоги 3 хвороби, з медичної допомоги та безробіття, сімейні й інші допомоги, та регулюються законодавством або галузевими (колективними) договорами. В їх фінансуванні переважно беруть участь працедавці. Важливою складовою частиною загальної системи пенсійного забезпечення є професійні (галузеві) пенсійні програми, а також аналогічні програми компаній, які здійснюють як обов'язкове, так i добровільне страхування конкретного виду соціального захисту.

Досвід розвинутих країн та країн з перехідною економікою свідчить про те, що наявність збалансованих систем пенсійного страхування є важливою 
умовою ефективної системи соціального захисту громадян похилого віку, та стабілізації політичної і соціальної ситуації в суспільстві.

Ключові слова: публічне управління фінансами, сфера загальнообов'язкового державного пенсійного страхування, зарубіжний досвід

Korol Tetiana Illivna Postgraduate Student, Department of Public Policy, Educational and Scientific Institute of Public Administration and Civil Service, Taras Shevchenko National University of Kyiv, A. Tsedika St., 20, Kyiv, 02000, tel.: (044) 284-69-50, https://orcid.org/0000-0001-5161-8503

\section{FOREIGN EXPERIENCE IN THE FIELD OF COMPULSORY STATE PENSION INSURANCE THROUGH PUBLIC FINANCIAL MANAGEMENT}

Abstract. The article presents an analysis of foreign experience in the field of compulsory state pension insurance with the help of public financial management and formulates on this basis generalizing conclusions for Ukraine.

The author notes that today in the world there are various models for building pension systems, which, in particular, are distinguished by the following features: the scale of state participation in the development and implementation of pension programs, sources of funding and the structure of pension expenditures; the structure of the population categories covered by a certain pension program; types of pension payments; the nature of pension fund management, etc. However, traditionally there are several models of pension systems that are considered as established.

Conclusions are drawn on public financial management in the field of compulsory state pension insurance in Latin America and the European Union. In particular, it has been revealed that in recent years, the EU countries have been characterized by the cessation of active and growing social reformism, the stabilization of the level of state social spending relative to the Gross Domestic Product, the reducing state influence and changing the methods and means of social regulation.

It has been established that in most countries with a market economy, other additional (mandatory and voluntary) social insurance programs have been developed, along with compulsory social insurance, covering old age pensions, sickness benefits, medical assistance and unemployment, family and other benefits and are regulated by law. or sectoral (collective) agreements. Employers are predominantly involved in their financing. An important component of the general pension system is professional (industry) pension programs, as well as similar programs of companies that carry out both compulsory and voluntary insurance of a particular type of social protection.

The experience of developed countries and countries with economies in transition shows that the existence of balanced pension insurance systems is an important condition for an effective system of social protection for the elderly and stabilization of the political and social situation in society. 
Keywords: public financial management, the sphere of compulsory state pension insurance, foreign experience

Постановка проблеми. Сьогодні в Україні дуже гостро стоїть питання публічного управління фінансами у сфері загальнообов'язкового державного пенсійного страхування. У процесі реформування системи пенсійного забезпечення в Україні з 2004 р. створюється трирівнева пенсійна система, проте другий рівень пенсійної системи досі не запроваджено. Сутність діючої солідарної системи (першого рівня пенсійного страхування із трьох) полягає в тому, що пенсії громадян, які закінчили свою трудову діяльність, фінансує нинішнє покоління (діє принцип солідарності поколінь). Впровадження накопичувальної системи (другого рівня пенсійного страхування) тісно пов'язане із фінансовою стабільністю солідарної системи пенсійного страхування.

Пенсійне забезпечення в Україні регламентується значною кількістю законів, що спричинюе надмірне розмаїття не тільки розмірів пенсій із солідарної системи, а також формул їх розрахунку та процедури призначення. Така ситуація не відповідає загальним правилам і принципам пенсійного страхування, що є однією 3 найголовніших підстав продовження реформи 3 урахуванням світового досвіду для дотримання принципу соціальної справедливості.

Актуальність цього дослідження прямо пов'язана 3 необхідністю ефективного публічного управління, зокрема у сфері загальнообов'язкового державного пенсійного страхування, адаптацією його до європейських стандартів, що пов'язано, з одного боку, з прагненням України до вступу в $С С$, а 3 іншого - 3 необхідністю вирішення питань пенсійного забезпечення мільйонів наших співвітчизників, які працюють за межами країни.

Аналіз останніх досліджень і публікацій. Під час проведення нами дослідження зарубіжного досвіду публічного управління фінансами у сфері загальнообов'язкового державного пенсійного страхування враховано науковий доробок С. Кадомцевої, Г. Костюніною, М. Кравченко, О. Крентовської, О. Линдюк, С. Мельник, В. Новікова, М. Папієва та ін.

Мета статті - сформувати для України узагальнюючи висновки за результатами аналізу зарубіжного досвіду публічного управління фінансами у сфері загальнообов'язкового державного пенсійного страхування.

Виклад основного матеріалу. Сьогодні у світі існують різноманітні моделі побудови пенсійних систем. Вони відрізняються за різними ознаками: масштабами участі держави у розробленні та реалізації пенсійних програм, джерелами фінансування та структурою пенсійних витрат; структурою категорій населення, які підпадають під дію певної пенсійної програми; видами пенсійних виплат; характером управління пенсійним фондом (далі - ПФ) тощо. Проте традиційно виокремлюють кілька моделей пенсійних систем, описують їхні характерні, типові риси та засади побудови, що розглядаються як усталені. 
Напрацьований досвід реформування пенсійних систем країн Латинської Америки (далі - ЛА) становить значний інтерес для покращення державного регулювання фінансового забезпечення пенсійної системи України. Латиноамериканські країни часто стикалися 3 проблемою бюджетного дефіциту, недостатнім фінансовим забезпеченням пенсійної системи. Завдання пенсійної реформи полягало в тому, щоб створити стійкий зв'язок між участю в системі і виплатами, зокрема за рахунок підвищення іiі прозорості. Передбачалося, що розподільчий рівень доцільно скоротити за рахунок введення накопичувального рівня. Реформи в країнах ЛА сприяли появі консенсусу в тому, що розвиток пенсійних систем повинен рухатися у бік “приватизації" і комбінування приватних і державних систем пенсійного забезпечення. Вважалося, що таке поєднання дозволить вирішити низку проблем не тільки в пенсійній, але і в інвестиційній сфері, сприятиме розвитку національних ринків капіталу. У цьому сутність чилійської пенсійної реформи 1981 р. По цьому шляху пішли Аргентина, Перу, Колумбія, Мексика, Уругвай, Болівія, Сальвадор, Коста-Ріка і ін. Були прийняті закони про створення багатокомпонентних пенсійних систем. Ці країни ввели обов'язкові накопичувальні компоненти пенсійних систем, але співвідношення їх 3 розподільчою системою, як і інші елементи цих систем, відрізнялися [1, с. 81]. У цих країнах реформування йшло по одному 3 наступних шляхів: а) впровадження накопичувальної системи (Чилі, Перу); б) реформування розподільчої системи (Бразилія); в) реалізація змішаної пенсійної системи 3 елементами розподільчої і накопичувальної систем (Аргентина, Колумбія).

Чилійські економісти виділяють чотири фундаментальні принципи своєї системи: індивідуальне накопичення капіталу зі свободою вибору; управління пенсійними рахунками приватною компанією; державна гарантія мінімальної пенсії; “солідарна відповідальність” пайовиків фонду у випадках настання інвалідності або пенсії по втраті годувальника (при індивідуальній відповідальності за розмір пенсії).

В Чилі відбулася повна заміна старої системи перерозподілу новою, заснованою на індивідуальній капіталізації засобів. Більшість країн ЛА повністю або частково відмовилися від державних систем соціального забезпечення на користь обов'язкових, повністю фондованих пенсійних систем 3 індивідуальними рахунками, визначеними внесками та недержавним адмініструванням. Цілями реформ було: покращення фінансового стану пенсійної системи, послаблення фінансового тягаря на державний бюджет, вирішення проблеми бідності серед людей похилого віку, зміцнення фінансових ринків, що, повинно було стимулювати економічне зростання. Реформування пенсійної системи в Чилі позитивно вплинуло на економіку, сприяло розвитку національної фінансової системи, здійсненню процесів приватизації [1, с. 96].

Недоліком тих реформ $\epsilon$ те, що, незважаючи на відносно велику чисельність учасників недержавних ПФ, рівень охоплення населення 
залишається недостатнім: новими пенсійними системами охоплено близько третини економічно активного населення країн регіону. Проблему загострюють застійні явища у державному економічному секторі багатьох країн ЛА, що призводять до скорочення чисельності платників пенсійних внесків.

Таким чином, основними висновками $з$ досвіду пенсійного реформування країн ЛА для України є: 1) залежність рівня пенсійного забезпечення від економічної ситуації в країні, зокрема рівня інфляції, об'єму зовнішнього і внутрішнього боргу, динаміки зростання зайнятості і безробіття, зростання оплати праці; 2) ефективність управління пенсійними коштами, зниження рівня ризиків вкладень і скорочення адміністративних витрат; 3) підвищення ролі держави як регулятора пенсійної системи, посилення наглядової функції держави за діяльністю адміністраторів; 4) збільшення економічно активного населення, що підпадає під пенсійне забезпечення за рахунок включення самозайнятих, підвищення питомої ваги реального сектора економіки [2, с. 20].

Важливо врахувати, перевірений практикою, досвід країн ЦС та Балтії, i вважається за доцільне використати його позитивних сторін в Україні як орієнтира для вдосконалення державного регулювання вітчизняної пенсійної системи. Ці країни успадкували солідарні пенсійні системи. У статті [3] досліджено пенсійні системи в 11 країнах: Болгарія, Литва, Естонія, Латвія, Хорватія, Чехія, Угорщина, Польща, Румунія, Словакія і Словенія. Вісім $з$ них: Болгарія, Естонія, Латвія, Хорватія, Угорщина, Польща, Румунія і Словакія провели реформи із створенням багаторівневої пенсійної системи. Всі країни різними шляхами поєднували три рівні у пенсійних системах. Перший рівень регулює параметри існуючих систем соціального страхування. Другий скорочує соціальне страхування на користь індивідуальних заощаджень. Третій заохочує нові можливості добровільних пенсійних заощаджень. Конкретне поєднання цих стратегій значно змінюється залежно від країни. Деякі країни докорінно змінюють свої пенсійні системи, інші пристосовують їх поступово і у висхідному порядку.

У зв'язку з формуванням обов'язкових накопичувальних систем другого рівня відбувається зміна ролі держави - вона стає інститутом, що здійснює регулювання пенсійної системи [4, с.19].

Пенсійний вік, формула нарахування виплат, спеціальні категорії працівників, скорочення пільг, пов'язаних з достроковим виходом на пенсію та збір пенсійних внесків - це ті аспекти пенсійної системи, де відбуваються значні коригування. Підвищення пенсійного віку у більшості країн, коливається до 3 pp. для чоловіків і до 6 pp. для жінок. У Польщі, Словенії пропозиції зрівняти пенсійний вік чоловіків та жінок були відхилені на користь подальшого збереження різниці. Литва і Чехія поступово підвищували фактичний пенсійний вік, інші країни пенсійний вік різко збільшили.

Ці країни переглянули формули нарахування пенсій, проте їх підходи в цьому питанні відрізняються. Зміни полягали в тому, що пенсії були більш 
персоніфікованими та пов'язаними із заробітком. Найбільше заходів у цьому напрямку було вжито Латвією та Польщею, де система встановлених пенсійних виплат була замінена так званою системою умовних встановлених внесків. За цією системою рівень пенсії працівника встановлюється після виходу на пенсію на основі обліку сплачених працівником внесків за життя. В Угорщині та Словаччині формула розрахунку пенсій є нелінійною, а також враховує тривалість трудового стажу (Литва і Естонія) [5, с. 385].

Змінено також умови виходу на пенсію. Зокрема, в Румунії встановлена нова система розрахунку пенсій, яка почала враховувати страховий дохід за весь період сплати внесків. Ці зміни дозволяють підсилити взаємозалежність внесків і пенсій. У більшості країн при нарахуванні пенсії збільшено кількість відпрацьованих років. Цей крок посилює відносини між виплатами та заробітком на все життя, спрямовані на заохочення більш тривалої участі у формальному ринку праці.

У постсоціалістичних країнах деякі уряди стандартизували правила нарахування виплат для працівників за рахунок скасування пенсійних пільг для окремих категорій. Чехія, Литва скасували такі пільги; Словенія фінансує їх окремо, а в усіх інших питання пенсійних пільг залишається на порядку денному національної політики (Естонія, Польща, Словацька Республіка) [6, с. 241].

Щодо другого рівня пенсійного забезпечення слід зауважити, що в Угорщині обов'язкова участь в накопичувальній системі обмежена особами, які вперше виходять на ринок праці, тоді як в Польщі і Латвії ця норма розповсюджується на всіх працівників, що не досягли 30 р., в Болгарії - 42 р.

До проблем розвитку пенсійного страхування в досліджуваних країнах відноситься стимулювання надходження внесків. Недостатність коштів в цих країнах обумовлена розвитком тіньової економіки, практикою заниження офіційної зарплати і виплатою “зарплати в конвертах".

Добровільні додаткові пенсійні плани націлені на те, щоб заохотити працівників брати активну участь у фінансуванні майбутньої пенсії, акумулюючи додаткові ресурси для пенсійних виплат. Майже всі країни обрали такий шлях щодо добровільних пенсійних заощаджень. Повільне економічне зростання спрацювало проти поширення добровільних схем у деяких країнах (Польща, Словакія), а в країнах 3 невеликою чисельністю населення і нерозвинутими фінансовими ринками приватні компанії не були зацікавлені у створенні фондів (Литва) [4, с. 12].

Щоб почати реформування пенсійної системи, деякі країни збільшили кількість альтернативних добровільних приватних пенсійних програм шляхом надання пільгового оподаткування (Словенія), або забезпечення відповідних виплат 3 національного бюджету (Чехія). В деяких країнах податкове стимулювання до добровільної участі виявилося дорогим, але ефективним для поширення добровільних схем [5, с. 388].

Таким чином, в цілому пенсійні реформи в країнах ЦЄ та Балтії утворили такі пенсійні системи, які перевершують колишні системи за такими 
показниками, як достатність, доступність з погляду величини внесків, стійкість і надійність. Зміна віку виходу на пенсію, скорочення пільг і зниження рівня пенсійних виплат привели до поліпшення фінансових показників. Необхідна диверсифікація інвестицій в міжнародному масштабі [4, с. 19].

Проблемами систем пенсійного забезпечення країн $\mathrm{CC} \epsilon$ : дефіцит бюджету; старіння населення; зміни в законодавстві тощо. Для їх вирішення було здійснено перехід до нових пенсійних систем, які стійкіші через свою диверсифікованість (складаються з державних і приватних ПФ), що поєднують схеми зі встановленими виплатами і схеми зі встановленими внесками) і через свій ринковий характер набагато краще захищені від політичних потрясінь.

Основним чинником трансформації пенсійних систем є глобальні зміни у демографічних та економічних параметрах, що характерно для всіх країн ЄС. У більшості цих країн рівень народжуваності є нижчим від рівня, необхідного для відтворення населення. Наслідком цього $є$ збільшення частки людей похилого віку, зменшення частки молоді та економічно активного населення середнього віку. Ця тенденція за прогнозами науковців посилиться загальним зростанням тривалості життя [7]. Раніше пенсійні системи країн ЄС формувалися виходячи із пріоритету соціальних цілей. Це зумовило досягнення в сфері пенсійного забезпечення, були створені достатньо надійні механізми гарантій мінімальних доходів пенсіонерам. Сьогодні на перший план виходять економічні цілі, що змінило акценти в пенсійній стратегії, які виходять із мінімізації соціальних цілей.

Фінансові, економічні та соціальні причини зумовили необхідність реформування пенсійних систем. Всі країни СС реформували свої пенсійні системи у зв'язку із скороченням бази внесків і збільшенням кількості отримувачів пенсій, що було спричинене спадом економічної активності. Щоб змінити однокомпонентну розподільчу систему вони здійснили іiі реформування. Тобто забезпечення фінансової стабільності пенсійних систем здійснювалося за рахунок структурних і параметричних змін у цих системах: підвищення віку виходу на пенсію; збільшення необхідного страхового стажу і періоду відрахувань до ПФ; скорочення пільг, пов'язаних 3 достроковим виходом на пенсію; зміна порядку індексації пенсійних виплат (пенсії індексувалися в залежності від подорожчання життя, а не прирівнювалися до номінального зростання оплати праці); стимулювання розвитку додаткових професійних накопичувальних пенсійних програм i схем індивідуального пенсійного страхування; збільшення розмірів страхових внесків і модернізація бази їх нарахування. Значна роль у реформуванні пенсійних систем відведена принципу “страхової нейтральності”, тобто розмір пенсії, залежить від суми внесків, сплачених до пенсійної системи протягом трудового життя.

Традиційні розподільчі системи домінують у пенсійному забезпеченні більшості країн ЄС. Державні пенсійні системи є значним джерелом доходів пенсіонерів. Зокрема, кількість людей, які забезпечується державним пенсійним страхування коливається від 25\% в Італії до 100\% в Швеції, 
середній рівень складає 50-70\% [8]. У Бельгії така система охоплює біля 70\% пенсіонерів, в Німеччині - 82\%. Розподільчі пенсійні системи сформувалися як базові державні системи, засновані на схемах фіксованих, або наперед встановлених пенсій i розрахованих із рівня доходів, 3 яких сплачувалися страхові внески. Відмінності між розподільчими системами стосуються механізму нарахування пенсії: в одних країнах вони сприятливі, в інших орієнтовані на мінімізацію виплат. В цьому контексті виділяють такі моделі: 1) англійська, заснована на єдиному розмірі пенсії, яка виплачується за наявності повного страхового стажу (Великобританія, Ірландія), або при умові постійного проживання (Нідерланди, Данія); 2) німецька і іспанська допомога залежить від рівня доходу; 3) змішана (Італія, Швеція), заснована на системі сплачених внесків [5, с. 387].

Другий рівень пенсійного забезпечення країн $\mathrm{CC}$ представлений професійними добровільними схемами (носить обов'язковий характер i регулюється колективними договорами). Професійні пенсійні системи широко представлені у Нідерландах, Франції, Фінляндії. В Італії розвинуті закриті професійні пенсійні системи. Відповідна політика, направлена на розвиток додаткових схем через механізми галузевих колективно-договірних угод, здійснюється в Іспанії та Німеччині.

Професійною системою пенсійного забезпечення покривається пенсія 75\% людей і більше в Данії, Нідерландах та Швеції, тоді як частина країн покривають 40-75\% (Бельгія, Німеччина, Ірландія, Великобританія), а більшість країн мають покриття менше 20\% (Італія, Австрія, Франція, Іспанія, Фінляндія, Португалія) [6, с. 346].

В Італії, Швеції сформована змішана модель, яка включає елементи розподільчих i накопичувальних механізмів - умовно-накопичувальна система. В межах цієї системи розподільчий елемент функціонує в реальних грошах, а накопичувальний елемент носить умовний характер.

Для забезпечення достатніх пенсій ЄС стимулює розвиток приватних пенсійних механізмів. Приватні пенсії необхідні для запобігання бідності осіб в старості. Основна проблема - ступінь обов'язковості пенсійних внесків в приватні ПФ. Держава не гарантує доходність інвестицій, а створює механізм контролю над ризиками роботи цих фондів.

Наявні теоретичні дослідження та практика сьогодення доводять, що пенсійна політика та практика їі реалізації нині стають більш ліберальними, прагматичними, орієнтованими не стільки на підтримку економічно слабких верств скільки на створення передумов для підвищення мотиваційного потенціалу, трудової продуктивної активності людських ресурсів [9]. Тому слушною є точка зору Крентовської О. щодо збереження літніх людей на ринку праці. Це сприяє покращанню державних фінансів, протистоянню негативного впливу старіння населення на економічне зростання і збільшенню чисельності працюючого населення. У країнах СС вживаються заходи державної політики для залучення працівників старшого віку, які поділяють на 
категорії: політика обмеження, політика заохочення $[10,11]$. Для більшості країн характерно те, що встановлено однаковий пенсійний вік для жінок і чоловіків: Італія, Франція, Швеція, Німеччина, Ірландія, Нідерланди, Португалія, Іспанія, Данія. Країн, де для жінок встановлено нижчий пенсійний вік на один рік - дві: Бельгія, Швейцарія. На п’ять років різниця у віці виходу на пенсію в Австрії, Великобританії [12]. В Італії пенсійний вік не змінено, але збільшено число років сплати страхових внесків, необхідних для призначення пенсії. До політики обмеження відноситься і скасування можливості дострокового виходу на пенсію (Бельгія, Данія, Фінляндія, Німеччина) [13]. Австрія, Португалія, Швеція враховує при розрахунку пенсій суми заробітку, отриманого протягом усієї трудової діяльності.

Політика заохочення спонукає пенсіонерів залишатися на ринку праці довше шляхом стимулювання відстрочення виходу на пенсію $[14$, с.17]. Так, у Швеції, пропрацювавши один рік після досягнення пенсійного віку людина отримає пенсію на 8-9\% більше, а не на 2-3\%, передбачених в більшості традиційних схемах встановлених виплат. В Італії працюючі пенсіонери звільняються від сплати внесків до розподільчої системи, в Австрії, Іспанії їм протягом періоду роботи зменшують тривалість робочого часу i додатково надають можливість отримувати часткову пенсію [7].

Цікавим для України є досвід можливостей поєднання пенсії за віком із доходами від зайнятості. Немає обмежень у Франції, Нідерландах. Існують обмеження в Данії, Фінляндії, Італії, Португалії, Іспанії тощо. Багато країн забороняють зовсім отримувати пенсію за умови продовження трудової діяльності [13].

Пенсійні системи країн, хоча і мають відмінні характеристики, однак основні елементи в них $є$ подібними. Для більшості національних моделей пенсійних систем, зокрема їх фінансових засад, характерні наступні ознаки:

- загальною рисою реформування пенсійних систем є суттєві масштаби та глибина здійснення пенсійного реструктурування;

- складна структура пенсійної системи;

- більшість країн скоротили свої національні пенсійні програми і замінили їх індивідуальними рахунками, які регулюються комерційними методами та ринковими механізмами;

- посилення ролі пенсійного страхування в пенсійному забезпеченні населення; обов'язковий характер пенсійного страхування;

- обов'язкове пенсійне страхування в більшості країн відіграє ключову роль, забезпечуючи відповідність пенсії трудовому вкладу;

- перерозподільча частина, яка реалізується в соціальній (базовій) пенсії зберігає своє значення для забезпечення мінімального доходу;

- пенсійні системи фінансуються за рахунок пенсійних страхових внесків роботодавців (страхувальників), найманих працівників (застрахованих) 3 можливою додатковою участю держави; 
- участь держави полягає у регулюванні, покритті дефіцитів солідарних ПФ, гарантуванні мінімального доходу/пенсії з державного бюджету;

- пенсійний вік встановлений не нижче 65 р. для чоловіків та 60 р. для жінок;

- відстрочення виходу на пенсію стимулюється підвищенням пенсії;

- наявність стимулів та умов для розвитку другого та третього рівнів пенсійної системи;

- послаблення першої складової пенсійної системи при посиленні iї другої складової і активному розвитку добровільного страхування

- поєднання розподільчих та накопичувальних систем;

- широке інвестування коштів, зібраних ПФ, в економіку;

- присутня альтернатива вибору системи пенсійного страхування, що дозволяє забезпечити високу гнучкість пенсійних систем;

- пенсійні страхові внески акумулюються в спеціальних фондах (касах), які, виступаючи в ролі страхувальника, виплачують пенсіі;

- значна увага держави приділяється питанням стабільності пенсійної системи, фінансовій стійкості ПФ;

- економічна і соціальна обгрунтованість основних параметрів пенсійної системи (тариф страхового внеску та коефіцієнт заміщення);

- форми та пропорції поєднання інститутів пенсійної системи залежить від соціальних доктрин суспільства (ліберальної, консервативної, соціалдемократичної тощо) і розвиненості фінансових та страхових інститутів

- зміна психології працівників, які усвідомлюють необхідність відраховувати внески з початку трудової діяльності.

Свропейський досвід функціонування пенсійних систем свідчить про те, що вони грунтуються на засадах страхування та адресності. Управління здійснюється соціальними партнерами: роботодавцями, застрахованими особами і державою.

Аналіз досвіду країн ЦЄ та Балтії у сфері державного регулювання фінансового забезпечення пенсійних систем дозволяє зробити висновки. 1.Процес реформування моделі державного регулювання фінансового забезпечення пенсійної системи не може супроводжуватися загостренням соціально-політичної та економічної ситуації. Тому проводити реформи може лише влада, яка користується авторитетом населення. 2. Сильна пенсійна політика має бути зваженою, обгрунтованою i спиратися на реальні можливості суспільства. 3. Успішне вирішення задач пенсійної системи вимагає збереження та укріплення соціальної ролі держави, забезпечення ефективного контролю за ресурсами, врахування регіональних особливостей і факторів в процесі реалізації соціальних програм [15, с. 32].

Оскільки Україна перебуває на ранній стадії перебудови, це дозволяє застосовувати досвід інших країн, які в окремих напрямках пішли далі, враховуючи переваги і проблеми окремих пенсійних систем країн світу, їхні функції, принципи побудови, організаційний, фінансовий механізми тощо. 
Тому розробка основ пенсійної політики і заходів по іiі реалізації для вирішення проблем державного регулювання фінансового забезпечення пенсійних систем в Україні повинна базуватися на аналізі того передового досвіду, який накопичений в різних державах [16, с. 95].

Висновки. Отже, за результатами аналізу зарубіжного досвіду публічного управління фінансами у сфері загальнообов'язкового державного пенсійного страхування сформульовано для України такі узагальнюючи висновки.

Для країн, що входять у Європейський Союз, в останні роки стає характерним припинення активного та зростаючого соціального реформізму, стабілізація рівня соціальних витрат держави відносно до ВВП, зниження державного впливу та зміна методів і засобів соціального регулювання.

Поряд 3 обов'язковим соціальним страхуванням у більшості країн 3 ринковою економікою отримали розвиток інші додаткові (обов'язкові та добровільні) програми соціального страхування, які регулюються законодавством або галузевими (колективними) договорами. Ці програми охоплюють пенсії за віком, допомоги 3 хвороби, $з$ медичної допомоги та безробіття, сімейні й інші допомоги. В їх фінансуванні переважно беруть участь працедавці. Важливою складовою частиною загальної системи пенсійного забезпечення в країнах 3 ринковою економікою $є$ професійні (галузеві) пенсійні програми, а також аналогічні програми компаній, які здійснюють як обов'язкове, так і добровільне страхування конкретного виду соціального захисту.

Досвід розвинутих країн та країн з перехідною економікою свідчить про те, що наявність збалансованих систем пенсійного страхування $є$ важливою умовою ефективної системи соціального захисту громадян похилого віку, та стабілізації політичної і соціальної ситуації в суспільстві.

В Україні для удосконалення чинної пенсійної система, яка наразі ще $\epsilon$ складною і незрозумілою для людей, а солідарна система не є самодостатньою, слід якомога скоріше впровадити другий рівень пенсійної системи, зокрема, для того, щоб встановити чіткі перспективи для майбутніх поколінь та забезпечити достатні ресурси для отримання виплат в літньому віці. Це підтверджує і досвід зарубіжних країн, у тому числі країн Європейського Союзу.

\section{Лimepamypa:}

1. Костюнина Г. М. Реформирование пенсионных систем в странах Латинской Америки / Г. М. Костюнина // Труд за рубежом. - 2007. - № 3. - С. 79-97.

2. Крентовська О. Проблеми збереження і розвитку людського потенціалу в умовах старіння населення України / О. Крентовська // Вісн. НАДУ. - К. : НАДУ, 2009. - № 4. C. 238-246.

3. Линдюк О. А. Пенсійна політика країн Центральної Європи та Балтії: сучасні підходи та уроки для України / О. А. Линдюк // Зб. наук. пр. НАДУ. - 2010. - Вип. 1. С. 237-247. 
4. Holzman R. Old-age income support in the 21st century: an international perspective on pension systems and reform [Електронний ресурc] / R. Holzman, R. Hinz - Washington: The World Bank, 2005. - 246 p. - Режим доступу : http://www-wds.worldbank.org/ external $/$ default $/ \mathrm{main}$ ?pagePK=64193027\&piPK=64187937\&theSitePK=523679\&menuPK=6418 7510\&searchMenuPK=64187283\&theSitePK=523679\&entityID=000090341_20050621120802\& searchMenuPK=64187283\&theSitePK=523679

5. Линдюк О. А. Європейський досвід державного регулювання фінансового забезпечення пенсійних систем / О. А. Линдюк // Актуальні проблеми європейської та євроатлантичної інтеграції України : матеріали 7-ї регіон. наук.-практ. конф. (Дніпропетровськ, 14 трав. 2010 р.) / за заг. ред. Л. Л. Прокопенка. - Дніпропетровськ : ДРІДУ НАДУ, 2010. - С. 385-388.

6. Линдюк О. А. Пенсійна політика країн Центральної Європи та Балтії: сучасні підходи та уроки для України / О. А. Линдюк // Зб. наук. пр. НАДУ. - 2010. - Вип. 1. - С. 237-247.

7. Мельник С. В. Механізм регулювання соціально-трудової сфери України : монографія / Мельник С. В. - К. : Видавництво “Соцінформ”, 2009. - 786 с.

8. Кадомцева С. Экономические основы системы социальной защиты / С. В. Кадомцева. - М., 1997. - 248 с.

9. Кравченко М. Основні підходи до реформування системи пільг в Україні / М. Кравченко // Державне управління та місцеве самоврядування : зб. наук. пр. / редкол. : С. М. Серьогін (голов. ред.) [та ін.]. - Дніпропетровськ : ДРІДУ НАДУ, 2010. - Вип. 3 (6). C. $155-164$.

10. Крентовська О. Запобігання негативному впливу старіння населення України на фінансово-економічні параметри суспільства / О. Крентовська // Вісн. НАДУ. - К. : Видавництво НАДУ, 2010. - № 4. - С. 199-207.

11. Крентовська О. Проблеми збереження і розвитку людського потенціалу в умовах старіння населення України / О. Крентовська // Вісн. НАДУ. - К. : Видавництво НАДУ, 2009. - № 4. - С. 238-246.

12. Новіков В. М. Розвиток і організація соціальної сфери (зарубіжний і вітчизняний досвід) / В. М. Новіков - Київ : Ін-т економіки НАН України, 2000. - 246 с.

13. Папієв М. Світовий досвід застосування соціальних стандартів // Економіка України, 1, 2004, с.4-8.

14. Папієв М. М. Реформування пенсійної системи в Україні : автореф. дис. на здобуття наук. ступеня канд. держ. управл. : спец. 08.09.01 “Демографія, економіка праці, соціальна економіка і політика" / М. М. Папієв. - К., 2004. - 22 с.

15. Тишин Е. В. Социальная защита и социальное обеспечение за рубежом / Е. В. Тишин - Санкт-Петербург : Ин-т социально-економических проблем Российской академии наук, 1994. - 36 с.

16. Линдюк О. А. Фінансове забезпечення пенсійної системи України: проблеми і шляхи вирішення / О. А. Линдюк // Актуальні проблеми державного управління : зб. наук. пр. ОРІДУ / [голов. ред. М. М. Іжа]. - Одеса : ОРІДУ НАДУ, 2010. - Вип. 1 (41). - С. 95-98.

\section{References:}

1. Kostjunina G. M. (2007). Reformirovanie pensionnyh sistem v stranah Latinskoj Ameriki [Reforming pension systems in Latin America]. Trud za rubezhom - Labor abroad, 3, 79-97 [in Ukrainian].

2. Krentovs'ka, O. (2009). Problemi zberezhennja i rozvitku ljuds'kogo potencialu v umovah starinnja naselennja Ukraïni [Problems of preservation and development of human potential in the conditions of aging of the population of Ukraine]. Visn. NADU - Visn. NADU, 4, 238-246 [in Ukrainian]. 
3. Lindjuk, O. A. (2010). Pensijna politika kraïn Central'noï Evropi ta Baltiï: suchasni pidhodi ta uroki dlja Ukraïni [Pension policy of Central Europe and the Baltics: modern approaches and lessons for Ukraine]. Zb. nauk. pr. NADU - Coll. Science. NADU Ave., 1, 237-247 [in Ukrainian].

4. Holzman R. Old-age income support in the 21st century: an international perspective on pension systems and reform [Elektronnij resurs] / R. Holzman, R. Hinz - Washington: The World Bank, 2005. - 246 r. - Rezhim dostupu : http://www-wds.worldbank.org/external/default/ main?pagePK=64193027\&piPK=64187937\& theSitePK=523679\&menuPK=64187510\&searchMe nuPK=64187283\&theSitePK=523679\&entityID=000090341_20050621120802\&searchMenuPK= $64187283 \&$ theSitePK $=523679$

5. Lindjuk, O. A. (2010). Evropejs'kij dosvid derzhavnogo reguljuvannja finansovogo zabezpechennja pensijnih sistem [European experience of state regulation of financial security of pension systems]. Proceedings from VII '7: VII naukovo-praktychna konferentsiia "Aktual'ni problemi Evropejs'koï ta Evroatlantichnoï integraciï Ukraïni» - The Seventh Scientific and Practical Conference «Actual problems of European and Euro-Atlantic integration of Ukraine». (pp. 385-388). Dnipropetrovs'k : DRIDU NADU [in Ukrainian].

6. Lindjuk, O. A. (2010). Pensijna politika kraïn Central'noï Evropi ta Baltiï: suchasni pidhodi ta uroki dlja Ukraïni [Pension policy of Central Europe and the Baltics: modern approaches and lessons for Ukraine]. Zb. nauk. pr. NADU - Coll. Science. NADU Ave., 1, 237-247 [in Ukrainian].

7. Mel'nik S. V. (2009). Mehanizm reguljuvannja social'no-trudovoï sferi Ukraïni [The mechanism of regulation of the social and labor sphere of Ukraine]. K. : Vidavnictvo "Socinform" [in Ukrainian].

8. Kadomceva, S. (1997). Jekonomicheskie osnovy sistemy social'noj zashhity [Economic foundations of the social protection system]. - M. [in Russian].

9. Kravchenko, M. (2010). Osnovni pidhodi do reformuvannja sistemi pil'g v Ukraïni [Basic approaches to reforming the system of benefits in Ukraine]. Derzhavne upravlinnja ta misceve samovrjaduvannja - Public administration and local government, 3 (6), 155-164 [in Ukrainian].

10. Krentovs'ka, O. (2010). Zapobigannja negativnomu vplivu starinnja naselennja Ukraïni na finansovo-ekonomichni parametri suspil'stva [Prevention of the negative impact of aging population of Ukraine on the financial and economic parameters of society].Visn. NADU - Visn. NADU , 4, 199-207 [in Ukrainian].

11. Krentovs'ka, O. (2009). Problemi zberezhennja i rozvitku ljuds'kogo potencialu v umovah starinnja naselennja Ukraïni [Problems of preservation and development of human potential in the conditions of aging of the population of Ukraine]. Visn. NADU - Visn. NADU, 4, 238-246 [in Ukrainian].

12. Novikov V. M. (2000). Rozvitok $i$ organizacija social'noï sferi (zarubizhnij $i$ vitchiznjanij dosvid) [Development and organization of the social sphere (foreign and domestic experience)]. Kiïv : In-t ekonomiki NAN Ukraïni [in Ukrainian].

13. Papic,v M. (2004). Svitovij dosvid zastosuvannja social'nih standartiv [World experience of social standards]. Ekonomika Ukraïni - Economy of Ukraine, 1, 4-8 [in Ukrainian].

14. Papiev, M. M. (2004). Reformuvannja pensijnoï sistemi v Ukraïni [Reforming the pension system in Ukraine]. Extended abstract of candidate's thesis. Kiev [in Ukrainian].

15. Tishin, E. V. (1994). Social'naja zashhita i social'noe obespechenie za rubezhom [Social protection and social security abroad]. Sankt-Peterburg : In-t social'no-ekonomicheskih problem Rossijskoj akademii nauk [in Russian].

16. Lindjuk, O. A. (2010). Finansove zabezpechennja pensijnoï sistemi Ukraïni: problemi i shljahi virishennja [Financial support of the pension system of Ukraine: problems and solutions]. Aktual'ni problemi derzhavnogo upravlinnja - Actual problems of public administration, 1 (41), 95-98 [in Ukrainian]. 